\title{
COVID-19 Pandemic as a Threat to Ukraine's Socio- Economic System: Materialization Features, Indicators and Consequences
}

\author{
By Ganna Kozachenko ${ }^{1}$, Yuriy Pogorelov ${ }^{2}$, Oleksandr Olshanskyi ${ }^{3}$, \\ Maiia Kramchaninova ${ }^{3}$, Victoria Vakhlakova ${ }^{3}$
}

\begin{abstract}
The purpose of the paper is operationalization of development processes' concepts in terms of threats to a government's socio-economic system on an example of a specific threat that is currently actively materializing itself - COVID -19. The research aims at structuring the process of threat's development to a government's socio-economic system. It shows negative changes in Ukraine's socio-economic system, their indicators and consequences inherent to the last stage of the threat's development process - the materialization stage. At all stages of any threat's development process, close attention has to be paid to catalysts and inhibitors - factors whose influence accelerates or inhibits the development of the threat. Regarding the COVID-19 pandemic threat's materialization, inhibitors can only be the decisions and actions of Ukraine's government and institutions combined with the dualuse economic model (improving the pandemic situation, mitigating its consequences, on the one hand, preventing the deepening of the economic crisis and bankruptcy of domestic business, on the other). The results of studying the process of a threat's development lay the methodological principles for development of the Strategy Ensuring Ukraine's Economic Security. The development of a threat to a government's socio-economic system from perspective of the process approach has not been systemically explored. The scientific researches of the article's authors lay the fundamental ground in this direction of economic securitology.
\end{abstract}

Keywords: government's socio-economic system, threat, development process, operationalization of development processes' concepts, COVID-19, consequences, changes

\section{Introduction}

The Law of Ukraine “Concerning Ukraine's national security” defines Ukraine's national security from the perspective of protective approach - as "...protection of sovereignty, territorial integrity, democratic constitutional regime and other Ukraine's national interests from existing and potential threats." (Law of Ukraine No. 2469-VIII, 2018, art. 1). Ukraine's fundamental national interest cover “... sustainable development of the national economy, of civil society and government, providing better quality and standard of living for the population" (Law of Ukraine No. 2469-VIII of June 21, 2018, art. 3). Sustainable development and therefore higher quality and improved population's standard of living are possible, if levels of economic and social security are high.

Precisely the economic security is a platform of the country's national security, makes for a tangible pillar of the national sovereignty, and as much results into some real

\footnotetext{
${ }^{1}$ National Academy of Internal Affairs, Ukraine 
opportunities to achieve other kinds of a government's safety, amongst which social security has crucial role to play. All types of security are linked together dialectically and not only by the generic word "security", but above all by having a society as their essential object (Mizer, 2012).

That is why satisfying a government's need for economic security, which involves timely detection and recognition of threats to the national socio-economic system, should constantly remain the center of attention for the counties' authorities, due to being one of the checkpoints on a way of shaping a government's economic policy and its legal support, as well as a counter-threat policy.

The choice of specific ways, tools, means and procedures for the protection of Ukraine's fundamental economy interests depends on the kind and nature of threats to the country's soci0-economic system, trends and features of those threats, and also on complementarity, owing to their ability to add up and reinforce each other, even transition into different ones, more serious in consciences.

\section{Methodology}

The research of the COVID-19 pandemic as a threat to Ukraine's socio-economic system was conducted within the bounds of post-neoclassical ontology characterized by enhancement of a collective nature in scientific and educational activities, consensual scientific knowledge and methodological pluralism. Methodological pluralism led to a common use of inherent and contextual approaches, both unveiling the inner substance of the word "threat" as part of protective approach, where it is one of the mandatory provisions. Post-neoclassical ontology's major principles led to a use of process approach and dialectic method. The process approach and the dialectic method views development of the threat to a government's socio-economic system in collaboration, correlation and interplay between the stages of this process. A logical element of the dialectic method led to understanding the peculiarities of threat's development process, and to their research of COVID-19 pandemic as an example of a threat to Ukraine's socio-economic system.

\section{Results}

\subsection{Key concepts of the protective approach in economic security}

Emphasis on threats to the national socio-economic system when it comes to achieving government's economic security means that the content of 'government's economic security" is viewed in the context of the protective approach - as a condition for a sustainable operation and development of a government's socio-economic system. This displays its susceptibility to threats of various nature and origin according to the currently existing needs, knowledge, attitudes. The higher the level of susceptibility of the socio-economic system, the worse its economic security. Respectively, vice-versa: the low level of susceptibility of the socio-economic system to threats implies high level of economic security (Kozachenko et al., 2020). Therefore, the identification of the type and nature of threats, the study of their development (process's features and dynamics) should be preceded by the following:

- clear grasp of the sense of the word "threat"; 
- threats examination in a context of a process approach, which provides with a procedural perspective on threat's emergence and development, demonstrating consequent phase changes, that if go undisrupted, end with threat's materialization and the consequences it brings;

- forecasting threats to a government's socio-economic system and the course of their development along with the study of its inhibitors and catalysts;

- predictive analysis of scenarios describing possible collaboration of threats to a government's socio-economic system in case of their materialization;

- predictive analysis of probable consequences from individual threats materialized, as well as from their combination, meanwhile testing the preparedness of a government's socioeconomic system to overcome those consequences.

A grounded opinion is, at present, that obscurity and incompleteness of the conceptual and categorical machine takes place at any level in economic securitology. The definition of the term "threat" is denoted in a manner that is abstract, ambiguous in phrasing, lacks recognition patterns, which is unacceptable, because this notion is crucial in economic securitology, most widely and frequently used.

The most comprehensive and detailed representation of the term «threat» is shown in (Didyk et al., 2021): any process or event, occurring within the internal or external environment of a socio-economic system, that under the certain combination of conditions and circumstances existing in a country or in its surrounding can inflict negative changes of various containment and extent, with predominantly negative consequences.

Nowadays the socio-economic system of every government faces not only various individual potential and real threats, but also combinations of threats engaged in different kinds and different strength of ties. The complexity of examining those sets of threats to the socio-economic system lies in their diversity, them originating from numbers of sources and their development residing at different levels of this process. Every threat to the socio-economic system has some peculiarities regarding background, further development and interaction with other threats, which necessitates the search for their intrinsic integrity (this search is a property of ontological scientific research applied in various fields of science). A threat to a government's socio-economic system as an objectively present phenomenon, potentially open to collaboration with other threats, requires analysis of its complementarity in terms of subsidiarity, interplay, mutual reinforcement and interaction with other threats different by nature of development, consequences and probability of their materialization. It is precisely the complementarity that demands unconventional ways of combating each threat's development and overcoming the consequences of an individual threat (of localized nature), as well as a set of threats. Overall, the complementarity category should be acknowledged as universal and central to studying the threats to Ukraine's socio-economic system, but at the same time as poorly researched.

\subsection{Indicators and consequences of a materialized threat to a government's socio- economic system}

The changes of negative nature in Ukraine's socio-economic system resulted from some materialized threats have certain consequences. A number of indicators, which can be described using quantitative values, evidences the emergence of negative changes in a 
government's socio-economic system. Threat's development can accelerate or stall under the influence of catalysts and inhibitors, respectively.

The consequences of negative changes inflicted on a government's socio-economic system resulting from some materialized threat convey different severity. Those consequences can be summarized as follows:

- the state of elements of a government's socio-economic system changes;

- connections and relations between the system's elements change (including, due to the changes in the state of the elements);

- through a change of state and relations between elements of a government's socioeconomic system happens the change of state and quality of an entire government's socioeconomic system;

- a change in the state and quality of a government's socio-economic system causes a change in the system's ability to perform its inherent functions (the scope of the functions executed decreases, the quality of their execution decreases, the execution of certain functions is terminated, etc.).

A change in relations and connections between elements of the government's socioeconomic system due to negative changes, resulting from a particular materialized threat have certain consequences that in some cases must and possibly can be overcome, in others - the overcoming is impossible, and they simply need to be taken into account when choosing directions and means of improving the state and functioning of a government's socio-economic system, as well as vectors of its development. In some cases, the consequences of changes in connections and relations between elements a government's socio-economic system, can (appropriately and necessarily) be used as the driving force for system's development.

A number of indicators evidences the emergence of negative changes in a government's socio-economic system.

In a general sense, an indicator is considered to be a feature of an object or phenomenon, which distinguishes it from other objects (phenomena). The plurality of indicators led to their division into characteristic and uncharacteristic, corresponding to the major and secondary properties, as well as into constant and random.

Indicators of negative changes in a government's socio-economic system caused by a materialized threat should be treated as system's new feature, which explains the difference between the current state of the system and its previous form that preceded the threat. Identifying the characteristic indicators of negative changes caused by a materialized threat enables the on-time response to these changes, preventing them from worsening and taking root until the point of transformation into some new system's properties. A set of indicators signifying negative changes in a government's socio-economic system caused by a materialized threat is potentially vast due to the multiplicity of threats to the system, their complementarity, them being at different stages of development, and due to a state of the country's economy at the time of threat. Such indicators are inseparable from their carrier - a government's socio-economic system, and do not have independent origin and livelihood, existing precisely due to materialized threats to the system.

Overall, there are grounds to consider relations between indicators and changes in a socioeconomic system caused by a materialized threat to the system as a certain aspect of the universal's ontological problem in economic security (universals are terms denoting 
properties or relations between phenomena and objects).

Development of a threat to a government's socio-economic system, as much as development of any other object (process), is influenced by certain factors that can both positively and negatively affect it, that is, can accelerate it (called development catalysts) or slow it down, stop (called development inhibitors) and thus change the process and results of development (Pogorelov, 2010, p. 196).

If we proceed with the concepts of development set out in [5], the threat development factor is a source of its actualization and arousal - the initial stages of a threat's development. Such factors act as processes or phenomena occurring in the external or internal environment of a government's socio-economic system, and can, with different intensity, directly or indirectly, positively or negatively affect the process of threat development and cause its results (Pogorelov, 2010, p. 197).

Consequently, factors of a threat's development by nature of their impact are reasons why threat endangers a government's socio-economic system and its development takes place, accelerates, slows down or stops. At all stages of this process, its vector is defined, the features of the process and time before the reach of an outcome, that is negative changes in the system, are determined. Such factors (catalysts and inhibitors) need considerable attention when examining threats to a government's socio-economic system. After all, the approved resolution and its implementation creates opportunities for increasing the influence of inhibitors and reducing the impact of catalysts on a threat's development. At economic securitology's macro level the empirical knowledge about various types of threats to Ukraine's socio-economic system has already been accumulated, its image shaped at the world's economic stage along with a generic picture of a negative impact following most serious threats' embodiment. Some of the threats described by means of indicators in (Didyk et al., 2021) are known and Ukraine tries to combat their materialization or its consequences (for example, rising technological backwardness, low rates of business processes' innovation and almost complete lack of their smartization, corruption, unsatisfactory state of legal protection of property and rights of economic agents, etc.).

However, new threats are constantly emerging both in Ukraine's socio-economic system and in its surrounding. The forecasting possibilities of their mere assistance are little. We are talking about poorly predictable and unpredictable (such as the "black swan") threats - allocated to a separate group in (Didyk et al., 2021), which are inevitable, the "black swan" phenomenon is described in (Taleb,2020). Insufficiently examined peculiarities of poorly predictable and unpredictable but inevitable threats' occurrence complicates the implementation of a government's combat strategy (it is impossible to prevent or eliminate such threats), leads to chaotic and unsystematic response, its low productivity (let alone efficiency) and in majority of cases to a government's inability to mitigate the consequences of such materialized threats.

\subsection{COVID-19 pandemic as a materialized threat to Ukraine's socio-economic system}

Certain specific threats best and most clearly demonstrate features of unpredictable materialized threats to a government's socio-economic system introduced with a purpose of operationalization of the main concepts studying their implementation 
in order to overcome the consequences. Thus, the unpredictable inevitable threats to a government's socio-economic system undoubtedly include the COVID-19 pandemic, announced by the U.N. in March of 2020. While in the beginning of the 21 st century the occurrence of such large-scale pandemics, proclaimed as one of the major threats to Ukraine's national security (Lehane, 2005, p. 77), was hypothetical, in 2020-2021 this treat has fully materialized and developed. Counteracting this inevitable threat - the uncontrolled spread of COVID-19 in Ukraine and in other countries, turned out to be impossible. The only option remaining was to slow down the process, mitigate the consequences and eliminate them as much as the country's resources allowed for it.

The threat of the COVID-19 pandemic in Ukraine, using the indicators provided in (Didyk et al., 2021), should be described as follows: a global, especially dangerous, natural, dynamic, chaotic threat with critical direct and significant indirect consequences, that has been materializing actively and for a long time. During the COVID-19 pandemic in Ukraine as of 1.05.2021, according to official statistics, there were 2,085,938 COVID-19 patients or $5 \%$ of the population (the population in Ukraine as of February 1, 2021 was 41,554.8 thousand people (Ministry of Finance.., 2021). Mortality rate from COVID-19 during the epidemic is $2.14 \%$ (although for other common diseases - cardiovascular diseases and neoplasms - mortality rate is higher).

The development of such a threat to Ukraine's socio-economic system as the COVID-19 pandemic is, in fact, a process where, according to its structuring provided in (Kozachenko et al., 2019) the stages of threat's actualization, arousal and materialization of a threat can be traced. These stages took place sequentially and the end of the short actualization stage was the beginning of an equivalently short stage of threat's arousal, and materialization quickly began after its arousal, as evidenced by respective indicators (Table 1).

Table 1. COVID-19 pandemic's development as a form threat to Ukraine's socio-economic system

\begin{tabular}{|c|c|}
\hline Development stage & Indicators of the development stage \\
\hline $\begin{array}{l}\text { threat's actualization } \\
\text { (January - March of } \\
\text { 2020) }\end{array}$ & $\begin{array}{l}\text { Receipt of unsystematic information about the first cases of the disease in } \\
\text { China and number of other countries } \\
\text { Spread of confusing and contradictory expert assessments and forecasts on the } \\
\text { likelihood of an epidemic in Ukraine } \\
\text { Lack of significant changes in Ukraine's economy (the state and dynamics of } \\
\text { economic development for this period were determined by the influence of the } \\
\text { ordinary) }\end{array}$ \\
\hline $\begin{array}{l}\text { threat's arousal } \\
\text { (March - May of } \\
\text { 2020) }\end{array}$ & $\begin{array}{l}\text { Drastic rise in numbers of COVID-19 cases } \\
\text { Panic among the public } \\
\text { Government's active implementation of individual anti-epidemic measures } \\
\text { aimed at combating the spread of COVID-19 (unsystematic, not always } \\
\text { thought though and coordinated with regional authorities) } \\
\text { Fast decrease of business entities' economic activity due to quarantine measures } \\
\text { Significant deterioration of micro- and macroeconomic government's rates }\end{array}$ \\
\hline $\begin{array}{l}\text { threat's } \\
\text { materialization } \\
\text { (May - August of } \\
2020 \text { ) }\end{array}$ & $\begin{array}{l}\text { Situation with COVID-19 incidence rate stabilized } \\
\text { Mitigation of coronavirus's restrictions and gradual resumption of business } \\
\text { entities' economic activity } \\
\text { Mild signals of negative changes' occurrence in a government's socio-economic } \\
\text { system } \\
\text { Mild positive dynamics of economic activity in the country }\end{array}$ \\
\hline
\end{tabular}




\begin{tabular}{|c|c|}
\hline Development stage & Indicators of the development stage \\
\hline (September - & Restoration of positive COVID-19 incidence dynamics \\
\hline December of 2020 p.) & Implementation by the government of certain anti-epidemic measures \\
\hline & Drop in business entities' economic activity due to the introduction of anti- \\
\hline & epidemic measures (once again unsystematic and in a number of cases \\
\hline & uncoordinated with regional authorities) \\
\hline \multirow{8}{*}{$\begin{array}{l}\text { (January of } 2021 \text { until } \\
\text { present) }\end{array}$} & Noticeable negative changes in a government's socio-economic system \\
\hline & Rise in numbers of COVID-19 cases \\
\hline & Poor dynamics of economic activity's recovery in the country \\
\hline & Significant strengthening of anti-epidemic measures in the country \\
\hline & Continuous drop in business entities' economic activity \\
\hline & $\begin{array}{l}\text { Expressive and noticeable changes in the negative nature in the socio- } \\
\text { economic system of the state }\end{array}$ \\
\hline & $\begin{array}{l}\text { Lack of organization in combating the spread of COVID-19, the authorities' } \\
\text { reactive response to changes in a government's socio-economic system }\end{array}$ \\
\hline & Evocative manifestation of the disparities in macroeconomic dynamics \\
\hline
\end{tabular}

Source The table is compiled using the results of studies of various authors, as well as provisions (Razumkov centre, 2020; Credit Suisse, 2020).

The features of the COVID-19 pandemic as a threat to Ukraine's socio-economic system are:

- speed of materialization;

- extent of materialization;

- extreme complexity of counteraction to materialization;

- acquisition by a purely biological factor for the period of the pandemic of super-powerful influence not only on governments' socio-economic system, but also on the political and legal sphere, intergovernmental relations and life of residents of all countries of the world; - extremely heavy consequences (a large number of deaths, significant resources spent on treatment, payments for sick-leaves, a significant decrease in the economic activity of business entities, etc.).

The large-scale COVID-19 pandemic, as much as any other threat's materialization, has caused numerous diverse, significant in both scale and consequences negative changes in Ukraine's socio-economic system. Such changes in a certain way deformed the system led to a deterioration in its condition and, respectively, functioning, as evidenced by failures in its functioning, reduced ability to perform them, due to incapability of fully financing a significant number of budget-funded programs among other things.

The most noticeable and large-scale changes of negative nature in Ukraine's socioeconomic system and the indicators testifying to them are shown in Table 2.

Table 2. Changes in Ukraine's socio-economic system caused by COVID-19 pandemic and indicators of their presence

\begin{tabular}{|l|l|}
\hline $\begin{array}{l}\text { Negative changes in Ukraine's } \\
\text { socio-economic system }\end{array}$ & $\begin{array}{l}\text { The indicators of negative changes in Ukraine's socio- } \\
\text { economic system }\end{array}$ \\
\hline $\begin{array}{l}\text { Deterioration of the socio-economic } \\
\text { system's functioning and its results.) }\end{array}$ & $\begin{array}{l}\text { Decrease in rates of economic sectors, making up the largest } \\
\text { share of the country's GDP (in the first quarter of 2021, the } \\
\text { decline in industry compared to the same period in 2020 } \\
\text { amounted to } 2 \% \text {, the agricultural sector - 5\%, freight traffic - } \\
6 \%, \text { construction - } 13 \%)\end{array}$ \\
\hline
\end{tabular}




\begin{tabular}{|c|c|}
\hline $\begin{array}{l}\text { Negative changes in Ukraine's } \\
\text { socio-economic system }\end{array}$ & $\begin{array}{l}\text { The indicators of negative changes in Ukraine's socio- } \\
\text { economic system }\end{array}$ \\
\hline & $\begin{array}{l}\text { Lack of consistency and complimentary measures aimed at } \\
\text { counteracting the spread of COVID-19 with priorities and } \\
\text { deadlines for implementing measures ensuring } \\
\text { macroeconomic stability (the highest priority of the } \\
\text { government's economic policy) } \\
\text { Growth of an underground economy }\end{array}$ \\
\hline $\begin{array}{l}\text { Deterioration of public administration's } \\
\text { quality }\end{array}$ & $\begin{array}{l}\text { Lack of consistency and complimentary measures aimed at } \\
\text { combating the spread of COVID-19 from state and regional } \\
\text { authorities. } \\
\text { Inconsistencies in the actions of state and regional } \\
\text { authorities on quarantine measures } \\
\text { Destructive effect of introducing hard lockdowns due to } \\
\text { their unplannedness, inconsistency in duration and terms, as } \\
\text { well as the lack of a recognition and penal system. }\end{array}$ \\
\hline $\begin{array}{l}\text { Rise of pressure on a social security } \\
\text { system }\end{array}$ & $\begin{array}{l}\text { Worsening of unsatisfactory state of a social security system } \\
\text { Lack of modern effective mechanisms for social security } \\
\text { services at regional levels }\end{array}$ \\
\hline $\begin{array}{l}\text { Decrease in level of country's financial } \\
\text { and budgetary feasibility }\end{array}$ & $\begin{array}{l}\text { Growth of the state budget's and off-budget trust funds' } \\
\text { deficit } \\
\text { Low level of financial support for patients' sick with } \\
\text { COVID-19 treatments and announced surcharges for } \\
\text { healthcare workers } \\
\text { Limited funds to support small and medium-sized businesses } \\
\text { compensating for their losses during the quarantine period }\end{array}$ \\
\hline $\begin{array}{l}\text { Decline in population's standards of } \\
\text { living }\end{array}$ & $\begin{array}{l}\text { Decrease in savings of the population (in } 2020 \text { decreased by } \\
17 \text { billion UAH compared to 2019) } \\
\text { Maintenance of long-term uncertainties and "fear" on } \\
\text { economic agents' side associated with the possibility of new } \\
\text { COVID-19 waves or the emergence of new pandemic } \\
\text { "attacks" }\end{array}$ \\
\hline Increase in social tensions in the public & $\begin{array}{l}\text { Contradictory nature of incoming information (in many } \\
\text { cases it was negative, not only complicating the proper } \\
\text { health protection, but first "dispersing" panic, and then - } \\
\text { indifference, while risks of infection yet remained high } \\
\text { Features and diversities of anti-epidemic measures in } \\
\text { different regions of the country }\end{array}$ \\
\hline $\begin{array}{l}\text { Change for major market participants in } \\
\text { standards of business conduct }\end{array}$ & $\begin{array}{l}\text { Decrease in revenues of service industries (retail, restaurant } \\
\text { business, tourism), "survival" of business entities under } \\
\text { quarantine restrictions that ban certain services } \\
\text { Decrease in number of job vacancies } \\
\text { Decrease in number of business entities } \\
\text { Expansion of earlier insignificant types of economic activity }\end{array}$ \\
\hline $\begin{array}{l}\text { Significant slowdown (and even } \\
\text { disappearance) of structural changes as } \\
\text { a necessary component shaping new } \\
\text { economic structure of the national } \\
\text { market }\end{array}$ & $\begin{array}{l}\text { Decreasing investments in human assets, primarily in terms } \\
\text { of education and science, beginning outflow of skilled } \\
\text { workers and young professionals of the newest scientific } \\
\text { fields }\end{array}$ \\
\hline
\end{tabular}

Source: The table is compiled using the results of studies of various authors, as well as provisions (Jalylo, et al., 2020; Yurchyshyn, 2021). 
Eliminating negative changes in Ukraine's socio-economic system caused by COVID - 19, listed in Table. 2, and bring the country's system back to its original (pre-pandemic) state is nearly impossible. Obviously, it is necessary to eliminate these changes as much as the government's resources allow for it (they also include the organizational and managerial element determining the quality of the decisions to be made and the quality of their implementation).

Changes of negative nature in Ukraine's socio-economic caused by COVID-19 pandemic have certain consequences (Table 3).

Table 3. The consequences of changes in Ukraine's socio-economic system caused by COVID-19 pandemic and indicators of their presence

\begin{tabular}{|c|c|}
\hline $\begin{array}{l}\text { Negative changes in Ukraine's socio- } \\
\text { economic system }\end{array}$ & $\begin{array}{l}\text { The consequences of changes in Ukraine's socio- } \\
\text { economic system }\end{array}$ \\
\hline $\begin{array}{l}\text { Deterioration of the socio-economic } \\
\text { system's functioning and its results. }\end{array}$ & $\begin{array}{l}\text { Unstable nature of economic development } \\
\text { Lack of consistency and complimentary measures aimed at } \\
\text { counteracting the spread of COVID-19 with priorities and } \\
\text { deadlines for implementing measures ensuring } \\
\text { macroeconomic stability (the highest priority of the } \\
\text { government's economic policy) }\end{array}$ \\
\hline $\begin{array}{l}\text { Deterioration of public administration's } \\
\text { quality }\end{array}$ & $\begin{array}{l}\text { Less control over a number of negative processes } \\
\text { happening in economics and society } \\
\text { More distrust towards authorities and their decisions } \\
\text { Necessity for explicit distinction in Ukraine's legislature } \\
\text { between jurisdictions of government authorities, regional } \\
\text { self-administration bodies and regional executive } \\
\text { authorities. }\end{array}$ \\
\hline $\begin{array}{l}\text { Rise of pressure on a social security } \\
\text { system }\end{array}$ & $\begin{array}{l}\text { Increase in unemployment rates (up to } 10 \% \text { according to } \\
\text { the ILO methodology) } \\
\text { Less possibilities of leaving for employment in European } \\
\text { countries }\end{array}$ \\
\hline $\begin{array}{l}\text { Decrease in level of country's financial } \\
\text { and budgetary feasibility }\end{array}$ & $\begin{array}{l}\text { Failure to take measures proposed to counteract the spread } \\
\text { of COVID-19 from financial and budgetary perspective } \\
\text { (the overall fiscal space and budget capacity covering } \\
\text { different time periods were not taken into account) } \\
\text { Inability to support small and medium-sized businesses, } \\
\text { which did not allow for their losses' compensation and led } \\
\text { to their liquidation or a major decrease in extent of their } \\
\text { activities } \\
\text { Action taken by the governmental authorities (of fiscal and } \\
\text { monetary nature), that can significantly accelerate the } \\
\text { economic dynamics } \\
\text { Amendments to the Law of Ukraine "Concerning the State } \\
\text { Budget of Ukraine in } 2021 \text { " on redistribution of } \\
\text { expenditures has frequented }\end{array}$ \\
\hline $\begin{array}{l}\text { Decline in population's standards of } \\
\text { living }\end{array}$ & $\begin{array}{l}\text { Drop in population's real incomes } \\
\text { Higher prices and inflation } \\
\text { Maintenance of long-term uncertainties and "fear" on } \\
\text { economic agents' side associated with the possibility of new } \\
\text { COVID-19 waves or the emergence of new pandemic } \\
\text { "attacks" }\end{array}$ \\
\hline
\end{tabular}




\begin{tabular}{|c|c|}
\hline $\begin{array}{l}\text { Negative changes in Ukraine's socio- } \\
\text { economic system }\end{array}$ & $\begin{array}{l}\text { The consequences of changes in Ukraine's socio- } \\
\text { economic system }\end{array}$ \\
\hline Increase in social tensions in the public & $\begin{array}{l}\text { Loss of } 44750 \text { human lives (as of 1.05.2021) } \\
\text { Propensity for public protest and frustration } \\
\text { Reformatted individual values and priorities }\end{array}$ \\
\hline $\begin{array}{l}\text { Change for major market participants in } \\
\text { standards of business conduct }\end{array}$ & $\begin{array}{l}\text { Changes in consumer's confidence } \\
\text { Wide spread of remote activities } \\
\text { Significant drop of business entities' investment intensions } \\
\text { Business entities stockpiling buffers (mainly financial } \\
\text { resources) } \\
\text { Business entities reformatting business models aimed at } \\
\text { strengthening sustainability } \\
\text { Difficulty predicting the reaction of the major market } \\
\text { participants to changes in the government's economic } \\
\text { policy }\end{array}$ \\
\hline $\begin{array}{l}\text { Significant slowdown (and even } \\
\text { disappearance) of structural changes as a } \\
\text { necessary component shaping new } \\
\text { economic structure of the national } \\
\text { market }\end{array}$ & $\begin{array}{l}\text { Limited investments in human assets, primarily in terms of } \\
\text { education and science, outflow of skilled workers and } \\
\text { young professionals of the newest scientific fields }\end{array}$ \\
\hline
\end{tabular}

Source: The table is compiled using the results of studies of various authors, as well as provisions (Applied Research Centre, 2020).

Among the general consequences of a materialized threat to Ukraine's socio-economic system, such as the COVID-19 pandemic are:

- the unpreparedness of state and local authorities to joint and coordinated counteraction to threats that have catastrophic consequences, has been revealed. However, to be fair, it should be noted that not only Ukrainian state and local authorities demonstrated such unpreparedness;

- clear inability of governmental institutions with appropriate jurisdiction to form an effective economic and legal mechanism minimizing negative changes in the economy and society associated with the spread of coronavirus and periodic implementation of antiepidemic measures, despite COVID-19 pandemic being long-term. The purpose of such mechanism should have been the creation of an environment facilitating activities of economic agents and the most important objects of social infrastructure (educational institutions, medical institutions, urban transport) in emergencies, as well as check on compliance with conditions created. And it is given the fact that back in 2020, the adopted Strategy on Ukraine's National Security of 2020, not only states that "... human being, one's life and health ... is the highest social value in Ukraine" (Ukraine's National Security Strategy, 2020), but is also recognizes the spread of coronavirus disease (COVID-19) as a threat to Ukraine's national security and national interests. The enactment of the provisions of Ukraine's Cabinet of Ministers' Regulation dating March 12, 2020 No. 211 (state's interference with human rights and establishment of a number of restrictions (Cabinet of Ministers..., 2020) is certainly an important element of this mechanism. However, it seems that this element remained the sole developed, and no mechanism consists of one element only;

- escalation of long-term existing, and therefore known contradictions, weak spots and unresolved issues in the system (for example, systemic problems in the healthcare and 
social protection departments, which have not been resolved during all the years of Ukraine's independence). Although, at the same time, the scale and duration of the COVID-19 pandemic to some extent served as an impetus to intensify the solution of those problems (telemedicine, online pharmacies, digital services in medicine (The Economist, 2020).

Development of any threat to a government's socio-economic system at all stages of this process requires close attention to its catalysts and inhibitors - factors, whose influence accelerates or slows down the development of a threat. The COVID-19 pandemic threat has long been actively materializing (that is, the process of this threat's development is at its last stage - the materialization stage), which significantly deformed Ukraine's socioeconomic system and changed its configuration. Nevertheless, the materialization of the COVID-19 pandemic threat does not imply abandoning attempts to slow down this stage of threat's development in some way and to mitigate the consequences, that is, to pay attention and direct efforts towards inhibiting the materialization of the threat.

As for COVID-19 pandemic threat's materialization, the only inhibitors there can be found are decisions and actions of the Ukrainian government and institutions, which absolutely must have an appropriate resource foundation. It is advisable to develop a government's economic model of a dual-use (improving the pandemic situation, mitigating its consequences, on the one hand, preventing the deepening of the economic crisis and bankruptcy of domestic business, on the other) and its active usage in the economic policy. In the context of such economic model, it is necessary to:

- launch large-scale national projects aimed at comprehensive support of the domestic business sector and jobs' preservation;

- transition to new mechanisms protecting domestic business entities, which take into account the changes in a government's socio-economic system that not only had already happened but taken root (reducing the credit and tax burden, establishing a digital infrastructure for business interaction with authorities, remote submission of electronic documents using a digital signature according to the requirements of the current legislation, transparency of electronic tax administration procedures);

- stimulation of economic activity, redirection of the unemployed to other types of economic activity, which requires their retraining.

The transition to the specified economic model of dual-use requires not so much financial resources, but organizational efforts accompanied by appropriate changes in Ukraine's legislation. At the same time, this economic model is capable of acting as a serious inhibitor for materialization of the COVID-19 pandemic threat, because it is still unknown how long the materialization stage will last.

\section{Conclusion}

The meaning of the "government's economic security" term is fully elaborated on by the protective approach that uses a "threat" as one if is imperative concepts. However, as of today in economic security of any level, the definition of "threat" is generic, vaguely described, lacking recognition criteria. A threat to a government's socio-economic system is viewed as processes and phenomena occurring in the external and internal environment of a socio-economic system, which, if there is a certain combination of conditions and 
circumstances within the state and its environment, may cause negative changes in the country's economy of different localization and scale with predominantly negative consequences.

No threat to a government's socio-economic system comes from nowhere: it is actualizing under the influence of a number of reasons, then arouses and materializes. That means the development of the threat should be considered as a process structured by stages. Changes of negative nature in Ukraine's socio-economic system resulting from a materialization of a certain threat have certain consequences. A number of signs indicates the emergence of changes.

Concepts of threat's development is operationalized on the example of a specific one that is currently actively materializes - the COVID-19 pandemic. The peculiarities of this threat's materialization directly derive from its characteristics: the threat is unpredictable, inevitable, global, especially dangerous, natural, dynamic, chaotic with critical direct and significant indirect consequences, which has been actively materializing for a while. Those characteristics of the threat define its materialization in Ukraine as a national catastrophe, which involves governmental resources of all kinds (financial, organizational, administrative etc.) in mitigation of the consequences.

In the development of such a threat to Ukraine's socio-economic system as the COVID19 pandemic is, the stages of threat's actualization, arousal and materialization can be traced, as evidenced by the indicators provided in the article.

The large-scale COVID-19 pandemic's, as much as any other threat's, materialization caused negative changes in Ukraine's socio-economic system, which in some way deformed this system, as evidenced by the serious consequences of such changes.

At all stages of any threat's development process, close attention has to be paid to catalysts and inhibitors - factors whose influence accelerates or inhibits the development of the threat.

Regarding the COVID-19 pandemic threat's materialization, inhibitors can only be the decisions and actions of Ukraine's government and institutions that should be combined with the dual-use economic model (improving the pandemic situation, mitigating its consequences, on the one hand, preventing the deepening of the economic crisis and bankruptcy of domestic business, on the other).

\section{References}

Applied Research Centre, (2020). Consequences of the COVID-19 epidemic and quarantine measures for leading sectors of the Ukrainian economy. Research on the results of in-depth interviews with owners and top managers of Ukrainian companies.

Cabinet of Ministers of Ukraine, (2020). On preventing the spread of acute respiratory disease COVID-19 caused by the coronavirus SARS-CoV-2 in Ukraine: Resolution of the Cabinet of Ministers of Ukraine of March 11, 2020 No. 211. https://zakon.rada.gov.ua/laws/show/211-2020$\% \mathrm{D} 0 \% \mathrm{BF} \# \mathrm{Text}$

Credit Suisse, (2020). Global Cycle Notes: Wait till next year. Credit Suisse. Investment Solutions \& Products United States. https://plus.credit-suisse.com/rpc4/ravDocView?docid=V7oRJE2AF-WZ1z

Didyk A., Kozachenko G., Pogorelov Y., (2021). Overview of threats to national economy with application of their classification criteria. Security management of the XXI century: national and geopolitical aspects: collective monograph. ISSUE 3. Prague (Czech Repulic), Nemoros s.r.o. Pp. 182-190. 
Jalylo Y.A., Bazylyuk Ya.B., Kovalivska S.V. et al., (2020). Ukraine after the coronavirus crisis - a way to recovery: scien. report K.: NISD. 304 p.

Kozachenko G. V., Pogorelov Yu. S., Bilousova A. Yu., (2019). Development of threats to enterprise activity. Security of the XXI century: national and geopolitical aspects: collective monograph. Prague Czech Repulic, Nemoros s.r.o., 134-140.

Kozachenko G.V., Pogorelov Y.S., Gerasimenko L.V., (2020). Assessment of the government's economic security using a constructive approach. Business Inform. №9. p. 44-55.

Law of Ukraine, (2018) On Ukraine's National Security: Law of Ukraine No. 2469-VIII of June 21, 2018. https://zakon.rada.gov.ua/laws/show/2469-19\#Text

Lehane V.M., Rudy V.M., (2005). The main ways of further development for Ukrainian healthcare system. Joint report. $168 \mathrm{p}$.

Ministry of Finance of Ukraine, (2021). The population of Ukraine. https://index.minfin.com.ua/reference/people/

Mizer A. A. (2012). Government's political security: problem statement // Scientific and educational problems of civil defense. №1. 89-95.

Pogorelov Y.S., (2010). Nature, driving forces and methods of enterprise's development: monograph. Kharkiv: AdvaTM. 352 p.

Razumkov centre, (2020). Economic liberations aimed at strengthening Ukraine's socio-economic development in the face of global transformations. https://razumkov.org.ua/uploads/article/2020 Economic freedom.pdf

Taleb N. N., (2020). Black Swan. Under the sign of unpredictability. M.: Colibry. 736 p

The Economist, (2020). The Dawn of digital medicine. Dec. 5th - 11th. P. 54-55.

Ukraine's National Security Strategy, (2020). "Individual Security - Security of the Country", approved by the Decree of the President of Ukraine No. 392/2020 of September 14, 2020. https://www.president.gov.ua/documents/3922020-35037.

Yurchyshyn V., (2021). Factors, components and results of the introduction and implementation of anti-crisis policy in certain countries of the world and in Ukraine. Forecast of socio-economic development of Ukraine in 2021. https://razumkov.org.ua/uploads/article/2021 ukraine economic forecast.pdf 